\title{
Women's Land Claims in the Acholi Region of Northern Uganda: What Can Be Learned from What Is Contested
}

\author{
Julian Hopwood \\ London School of Economics, London, U K \\ J.Hopwood@lse.ac.uk
}

\begin{abstract}
Women are often understood to be highly marginalised in typical African customary land regimes. The research presented in this article found that in the Acholi region of northern Uganda this is not the case. The crisis of land conflict that followed the twenty-year LRA insurgency and mass rural displacement has seemingly passed, notwithstanding a minimal contribution from the formal justice, law and order sector: local state actors as well as clan elders are mediating and adjudicating disputes on the basis of custom. However some social institutions, in particular traditional marriage, have been deeply affected by displacement and the consequent poverty. In this context, custom appears to be becoming more responsive to the needs of women, including those who are divorced or separated. While women's customary land claims are often challenged, they appear to be generally respected and supported by communities and those with responsibilities for settling disputes.
\end{abstract}

\section{Keywords}

customary land - land conflict - women - Uganda - Acholi

\section{Introduction}

In March 2013 the Ugandan Ministry of Land, Housing and Urban Development published a new land policy after a number of years of consultations. ${ }^{1}$

1 Ministry of Land, Housing and Urban Development (MLHUD), The Uganda National Land Policy (March 2013) pp. 17-18.

(C) JULIAN HOPWOOD, $2015 \mid$ DOI 10.1163/15718115-02203005

This is an open access article distributed under the terms of the Creative Commons Attribution-

NonCommercial 4.o (CC-BY-NC 4.o) License. http://creativecommons.org/licepses/by-nc/4.0/m๑4/26/2023 09:17:58AM 
Although as much as 9o per cent of Ugandan land is 'customary', the policy devotes to this topic only one short chapter. This does, in deference perhaps to some 30 years of policy debate, identify some measures to secure customary tenure rather than proposing its immediate elimination. However the actual steps identified are essentially the individualisation, privatisation and formalised tenure that it assumes are the inevitable evolutionary end-point for African customary land. ${ }^{2}$ In the policy, the proposed land title of 'Customary Tenure' is a stage on the path to freehold registration, and while there is recognition that some lands may be collectively held, the focus is on a type of commons found only in certain regions, neglecting the collective lands found in others. It does envision a (currently lacking) formal role for customary leaders in the settling of land disputes, though there is no acknowledgement that those who carry authority in respect of land management and dispute resolution might vary in different ethnic regions. ${ }^{3}$

The policy proposes land law reforms of a kind that represent a regression to colonial and early neo-liberal positions from the Land Act of $1998 .{ }^{4}$ Although

2 See I. Yngstrom, 'Women, Wives and Land Rights in Africa: Situating Gender Beyond the Household in the Debate Over Land Policy and Changing Tenure Systems', 30:1 Oxford Development Studies (2002) pp. 21-40, for a rejection of evolutionary theories in respect of customary land.

3 In the policy's customary land concerns and proposals, the advocacy of the Land and Equity Movement in Uganda (LEMU) can be discerned. Cf.e.g., R. Knight et al., Protecting Community Lands and Resources: Evidence from Uganda (Namati, LEMU and IDLO, Kampala, 2014). Problems in this and other reports and advocacy literature include referring to 'northern Uganda' when the custom it refers to is specific to the Lango Sub-region, or even more local. LEMU's recommendations follow the late Kenyan jurist Okoth-Ogendo, who on the one hand eloquently described how vastly, indeed metaphysically, different African land custom is from Western law's treatment of land as a commodity; but on the other asserted that it can be readily codified and incorporated into formal law. LEMU similarly seeks the incorporation of the customary into the formal system, seeing this as a means to ensure its consistency and its respect for women's constitutional rights. Mahmood Mamdani has provided a partial critique of LEMU's arguments but also declines to see African, or at least Ugandan, land custom as divers and complex. See M. Mamdani, The Contemporary Ugandan Discourse on Customary Tenure: Some Theoretical Considerations (Makerere Institute of Social Research, MISR Working Paper No.13, Kampala, 2013).

4 See A. Manji, The Politics of Land Reform in Africa: From Communal Tenure to Free Markets, (Zed Books, London and New York, 2006) on the problems - and neo-liberal politics - of land law reform; L. Alden Wily, Governance and Land Relations: A Review of Decentralization of Land Administration and Management in Africa, (International Institute for Environment and Development (IIED), London, 2003) which thoroughly documents the strengths and weaknesses of the 1998 Ugandan Land Act. 
the latter has been widely criticised, it has been for the lack of its implementation and affordability rather than its intentions and substance. Both the Act and the Policy have a stated aim to protect women's constitutional rights to equality in respect of customary land. Uganda's different ethnicities share a tradition, identifiable in contemporary custom, of patriarchy; if you ask most Ugandans, they will tell you something to the effect that 'women cannot own land', though this is actually not the case. In respect of formally tenured land, women have equal rights to men to buy, sell and own land (although other inequalities mean they more rarely do). While in respect of customary land, it is essentially the case that individuals of neither gender 'own' land, rather that the types of claims men and women can make for use of or control over land differ.

The findings presented here are intended to address some of the above issues. They arise out of work conducted in 2012 under the United Nations Peacebuilding Fund (PBF), which commissioned the development of a Land Conflict Monitoring and Mapping Tool (LСммт) for the Acholi sub-region of northern Uganda. ${ }^{5}$ This undertook a comprehensive mapping of land disputes, identifying trends within the area most affected by the northern Ugandan conflict, the Lord's Resistance Army (LRA) insurgency. This twenty-year conflict had led to the eventual displacement of the entire rural population of Acholiland (as well as more partial displacement in neighbouring regions), in some cases for more than a decade. The appalling internal displaced persons (IDP) camps eventually emptied after the end of the conflict on Ugandan soil in 2006 (it has continued in other countries), but the main exodus from the camps was between 2008 and 2010. As the oral records of land claims had been thoroughly disrupted and in some cases lost when a large part of a generation of elders had died in the camps and boundary markers had sometimes disappeared or become unrecognisable, expectations of land-related chaos were widespread amongst government and humanitarian agencies overseeing return.

Historically, Acholi land customs developed in an environment of extensive tracts of open land, some of it used, occupied and managed by communities, other parts unused and unoccupied, but perhaps technically part of a polity potentially tolerant of settlers. ${ }^{6}$ Here, the notion of 'claims' may have more traction than that of 'rights', and this complicates the challenge of defining

5 J. Hopwood and R.R. Atkinson, Final Report: Land Conflict Monitoring and Mapping Tool for the Acholi Sub-Region (United Nations Peacebuilding Programme and Human Rights Focus, 2013).

6 F.K. Girling, The Acholi of Uganda (H. M. Stationary Office, London, 1960). 
land disputes, given that a degree of negotiation is inherent in all land occupation and use. If negotiation is inherently part of land access, then so must be argument, and sometimes disagreement or quarrel. The point at which this might better be described as a dispute is something that perhaps only those engaged in the whole process are equipped to answer. Arguments about land within families and clans have probably always been ubiquitous and set about with systems for maintaining, and restoring where necessary, normal and harmonious relations.

The LCMMT research was concerned with those disputes that challenged communities, whether through violence or social strife, or which threatened individuals or groups with landlessness, or in some other way generated discord. Rather than risk limiting the potential range of challenges, we asked actors at a certain level - Parish - to report on problematic disputes. As these were leaders of communities with typically about 5,00o members, we hoped to avoid the inclusion of routine arguments that are endemic to the system. The spread of responses reporting from around 300 rural parishes suggest that respondents interpreted the brief fairly consistently.

As well as general dispute data, the tool collected information on clan distributions in around 70 per cent of the roughly 300 rural parishes in the subregion; and detailed descriptions of 1,320 disputes. 202 of these involved women or female-headed households as one or both of the principle parties to the dispute. ${ }^{7}$ Further interviews during January 2014 allowed for an update of ongoing disputes involving women as principle parties from September 2012.

LCMMT findings showed a steep decline in overall numbers of land disputes between October 2011 and September 2012, and high rates of resolution. This contradicted assumptions about the scale and trend of land disputes in Acholi and the consequent implication that local dispute resolution mechanisms were failing. It also found wide variation across Acholi in the communal bodies that control customary land. The research reported here seeks to look at issues of women's land security. The approach follows Johan Pottier, who argues that:

7 The descriptions of disputes are not random, but selected by informants, probably on the basis that these were the ones they were most familiar with. If so, they are likely to be representative. However it is important to note that other factors may have come into play. One possibility is that, as dispute resolution actors, some respondents might have avoided or distorted their reports of cases where they had been compromised through bribery, intimidation or had otherwise been involved in an unfair resolution. Overall however, the scale of the research means that it offers an interesting and roughly accurate picture of numbers and types of disputes significant at parish-level. 
The all important point is that we - analysts and policymakers alike must get beyond the currently popular, but excessively restrictive view that women's customary claims to land are always 'secondary' to men's. Without in any way diminishing the severe insecurities that women face, it must be recognised that the notion of a gradual weakening or extinction of women's rights in land is by no means inevitable. We must abandon such evolutionary thought, and instead pay full attention to the proliferation of claims and counter-claims that can be made - and are being made - in the name of custom. Like the colonial courts, contemporary policy arenas that espouse evolutionary models of customary land law are missing out on the ongoing dynamic of claims and counterclaims. ${ }^{8}$

This then is an examination of the claims and counter-claims made by women and by those seeking to displace them, usually on the basis of custom. It also examines how these claims are put forward and the processes involved in deciding them. The descriptions discussed have been provided by community leaders responsible for mediating and sometimes adjudicating these claims and, as such, offer a perspective on women's customary land security as it stands now.

I argue from these findings that the hybrid local authorities in Acholi are largely supportive of a range of kinship and marital claims to land made by women. Formal justice processes are not entirely absent, as they are sometimes invoked by those with the resources to do so, but are largely irrelevant as the higher courts lack both moral authority and the means to enforce their rulings. This has major implications for land policy and law reform.

\section{Background}

Customary land is, throughout much of Sub-Saharan Africa, also communal land. However the nature of the communal bodies in control varies substantially and this has significance for how customary land is managed, how its practices evolve in relation to external factors, which members of the communal body have stronger and weaker security of access and what threats they face. In Acholi, clans (kaka), as opposed, say, to chiefdoms, extended families

8 J. Pottier, 'Customary Land Tenure in Sub-Saharan Africa Today: Meanings and Contexts', in C. Huggins and J. Clover (eds.), From the Ground Up: Land Rights, Conflict and Peace in SubSaharan Africa (African Centre for Technology Studies and the African Security Analysis Programme of the Institute for Security Studies, 2006) p. 67. 
or households, have historically been the allocators and guarantors of their members' land 'rights', and so it is significant to consider the form they took in the past and how that may have changed in the present.

Clans tend to be defined in terms of kinship. In Acholi, clans are, and would seem to have long been, something more fluid and complex. As described historically by Crazzolara, Girling and Atkinson, the notion overlapped with, but was not identical to that of a village (gang), a physical, geographical entity. ${ }^{9}$ While there was a core agnatic lineage group to each clan/village, other residents included more than just the wives who had married into the clan. Refugees from other clans, often related by marriage - 'in-laws' - were and are a ubiquitous grouping, sometimes settling in a particular part of the village. A daughter returning to one of her parental clans with her husband, following difficulties of some sort in the husband's clan/village was and is a common scenario. However friends, and immigrants from other clans, tribes and regions usually also make up the mix..$^{10}$

The extent to which these others retain 'outsider' identities depends on many factors, including the strength of their ties to their clan of origin, whether they have integrated well, are good and helpful neighbours, have played an active part in clan/village affairs and the length of time or number of generations they have stayed. In pre-colonial times, this was happening in an environment where land was abundant, where, up to a point, the clan/village was stronger in terms of security if there were more members, and where newcomers brought new ideas, socially and economically.1 ${ }^{11}$ This meant that clans/villages often had good reasons to be inclusive to those who integrated. In some parts of Acholi some of these circumstances still apply, though population growth during the period of displacement has tended to reduce the perception that there is ample land.

Historically, clans were not static entities. As a social unit engaged in a range of cooperative activities, including collective farming, and without a strong central administrative hierarchy, there was perhaps an optimum size. Villages typically had a population of as few as 200 up to several thousand, but typically $300-400 .{ }^{12}$ If they grew much larger, they could become unwieldy given the

See J P. Crazzolara, The Lwoo, Vol. 3: Lwoo Traditions (Instituto Missioni Africane, Verona, 1954); Girling, supra note 6; R. R. Atkinson, The Roots of Ethnicity: The Origins of the Acholi of Uganda (Fountain Publishers, Kampala, 2010).

$10 \quad$ Atkinson, supra note 9, p. 15.

11 Girling, supra note 6, p. 180 talks of vast areas of unsettled bush, albeit usually conceived as hunting grounds specific to a clan or chiefdom, when he was there in the 1950 .

Atkinson, supra note 9, p. 76 . 
degree of collectivity. Quarrels might also lead to people leaving a clan. Such splits within clans/villages might involve individuals leaving on bad terms or being expelled, through to extended families leaving by mutual agreement with the rest, as pioneers establishing a new branch of the clan in a different location.

The resulting entities might be understood by their members to be linked as a single lineage/clan/kaka, made up of several sub-clans (doggola), which might be localised within a single chiefdom (see below) or spread across more than one. Over time, these entities might evolve into distinct clans or remain more or less closely linked by some or all of such practices as prohibited intermarriage, collective liability for blood money and openness to movement between populations. This mobility and flexibility around inclusion has led to issues of clan identity, and of ancestral clan land, being complex, changing over time, contested and negotiated by clan elders, and today often deeply unclear to younger clan members and outsiders.

Clans usually existed within chiefdoms in which spiritual and political authority of a kind was held by a royal chief [rwot moo], himself head of a royal (lo-kal) clan. As Girling puts it:

Although the Rwot was the political head of the domain, he had no coercive machinery for enforcing his decisions. It may even be doubted whether he had decisions of his own which he wished to enforce; the policy of the domain was the result of the reconciliation of the separate interests of the constituent village-lineages. ${ }^{13}$

Each pre-colonial chiefdom controlled a substantial geographical area and was made up of a royal clan and a variable number of commoner (lo-bong) clans. When a clan split as described above, the new entity might seek land in the same chiefdom or travel to a different chiefdom and request the chief to grant an area of land there. This might also happen if a clan was forced to relocate due to drought, disease, war or other catastrophe. Given the vast areas of land and the small population, the arrival of a new clan in a chiefdom tended to be beneficial to both parties. A new clan might be granted a tract of land by a chief within his domain, justifying his title of won lobo, 'father of the land'. However, once this had happened, the clan would become responsible for internal land allocations, calling on the chief to mediate in cases of external disputes with another clan or chiefdom.

13 Girling, supra note 6, p. 100. 
Under colonialism, this system was subverted in numerous ways, including forced population movements, in particular from the west of Acholi near the Nile to along the new road north to Sudan. Girling often writes with a valedictory tone about Acholi social organisation as he observed it in the early 1950s, 20-30 years after this disruption occurred. ${ }^{14}$ However, while the picture of villages and their composition and association with clans is today extraordinarily complex in many places due to population movements since the 1920s, the tradition of mutable and mobile clans has apparently resulted in today's Acholi villages manifesting a substantial degree of social continuity with their precursors. What does seem to have become more variable is the degree to which kinship plays a part in village organisation. Allen describes collective farming groups amongst the Acholi in southern Sudan in the 1980s, which ranged from single kinship groups to collections of kinships to seemingly non-kinship based groups including both Acholi and Madi people. ${ }^{15}$ LCMMT findings suggest a similarly complex pattern in contemporary Acholi, with some villages in which a single clan predominates, others that are far more mixed.

Colonial attempts to impose central authorities in Acholiland, and equivalents of Western law and justice systems, seem to have largely revolved around individual appointments: no attempts to codify Acholi customary law, whether in relation to land or any other matters, appear to have been made during the Protectorate or indeed until very recently. ${ }^{16}$ Such factors impact the form and nature of land claims, land management and land dispute resolution for any customary land, and whether they evolve in the direction of codification. In Acholi, the principles of land custom and claims are, in their essence, negotiable.

14 Girling, supra note 6.

15 T. Allen, 'Kwerte and Kwere: Acholi Farm Work Groups in Southern Sudan', 3:2 Manchester Papers on Development (1987) pp. 6o-92.

16 Girling, supra note 6, p. 85 recounts Postlethwaite, the first District Commissioner of Acholi recording Acholi customs "as I hear them", but this remained unpublished; see also A. Macdonald, Justice in Transition? Transitional Justice and Its Discontents in Northern Uganda, (PhD Thesis, Kings College London, 2014). In 2008, the formally recognised cultural leadership body, Ker Kwaro Acholi, representing the pre-colonial chiefdoms or domains, published Principles and Practices of Customary Tenure in Acholiland, [Acholi Luo version: Cik me loyoki kit me tic kingom kwaro iAcholi] (J. B. Enterprises, Gulu, 2008). This was followed by Law to Declare: the Acholi Customary Law (J.B. Enterprises, Gulu, 2009). 


\section{$3 \quad$ Findings}

\subsection{Mediation and Adjudication}

The Land Conflict Monitoring and Mapping Tool identified a steep decline in numbers of land disputes across Acholi, with around 4,00o during the sixmonth period October 2011 to March 2012 and just over 2,000 in the period April to September 2012; there were just over 1,00o current, on-going disputes in September 2012.

To the extent that individual dispute descriptions are representative, it is probable that there were about 200 (18 per cent of the total) ongoing parishlevel disputes involving women/female-headed households as principle parties in September 2012 in Acholi. In 33 per cent of the disputes examined, the parties have a close family relationship, while a further 30 per cent are members of the same extended family and 16 per cent members of the same subclan or clan. Disputes involving a female headed household are substantially more likely than all disputes to be intra-family (63 per cent compared to 33 per cent).

Rates of dispute resolution were consistently high, with a majority being resolved within six months, implying that community level dispute resolution mechanisms are effective and becoming more so. It seems that the natural habitat of the land grabber, extensive in the chaos that ensued during and immediately after the return of the population from displacement camps mainly between 2008 and 2010 - has shrunk considerably. ${ }^{17}$ Local Councils I (Village) and II (Parish) have to a large extent now become 'embedded' in Acholi:18 although for many years these entities were compromised by the war and ensuing antipathy between the National Resistance Movement (NRM) government and most Acholi. In fact, their grass-roots democratic nature resonates strongly with Acholi traditions of decision-making in village meetings. Overlap of personnel and function between government and customary local management and justice administration has been a persistent feature. ${ }^{19}$

In 2013 the mandate of Parish Councils (LCIIs) to hold courts to adjudicate land disputes was withdrawn. The failure to hold Village Council and Parish Council elections since 2002, ostensibly due to lack of funds, had raised

17 Hopwood and Atkinson, supra note 5.

18 H.E. Porter, 'Justice and Rape on the Periphery: The Supremacy of Social Harmony in the Space Between Local Solutions and Formal Judicial Systems in Northern Uganda', 6:1 Journal of Eastern African Studies (2012) pp. 85-86.

19 C. Leys, Politicians and Policies: An Essay on Politics in Acholi, Uganda, 1962-1965 (East African Publication House, Nairobi, 1967) pp. 19-21. 
questions as to these bodies' legitimacy. This was especially pertinent in respect of Parish Councils as dispensers of formal justice. In theory this has left a vast unfilled gap in the land dispute resolution process. In practice, however, the suspension of the supposed formal, adjudicative processes of Parish courts seem not to have interfered with what has long been a customary process of mediation by leaders involving communities. As one Parish councillor described a case to us, "[t]he dispute was resolved before the Parish Council, though it was not like a court ruling, but like mediation through mutual understanding of both parties and the community members". ${ }^{20}$

In fact there are many reasons why community land dispute resolution may be effective: decisions made by individuals or small groups, whether of customary leaders or government at every level, that are suspect, being seen as corruptible. By contrast, communities working as large groups representing many interests and perspectives are (relatively) trusted. They also usually contain participants with extensive knowledge of the individuals involved and of the land in question. A Parish Chairman, responsible for a formal court process until recently, nonetheless thought "there should be involvement and active participation to settle land disputes by youths, elders, women, clan leaders and religious leaders. And no courts or involvement of political leaders". ${ }^{21}$

Moreover there are cultural issues with the whole concept of adjudication by leaders. In Acholi tradition and custom, this was not one of the functions of clan or chiefdom leaders, unless it was in a highly consultative and inclusive fashion. 'Customary justice', as introduced by colonial authorities, was, according to Girling who observed it, far from customary, and frequently despotic. ${ }^{22}$ Local justice, or perhaps 'social ordering' would be a better term, administered by appointed or elected functionaries, has continued in various forms - including the current local council system - under the various governments of independent Uganda. 'Social ordering' has tended to be variably based on custom in its identification of wrongdoing, process of decision-making, and ideas of appropriate resolutions, but obliquely and to a small degree on state law and notions of formal justice. ${ }^{23}$

\footnotetext{
20 LCII Councillor, Ongako, Gulu, February 2014.

21 LCII Chairman, Palabek Kal, Lamwo, August 2012.

22 Girling, supra note 6, p. 196.

23 B. Jones, Beyond the State in Rural Uganda (Edinburgh University Press, Edinburgh, 2009) p. 76; J. Hopwood, Elephants Abroad and in the Room: Explicit and Implicit Security, Justice and Protection Issues on the Uganda/South Sudan Border (London School of Economics and Political Science, London, 2015).
} 
Partly, this can be understood as a natural consequence of having justice administered by untrained, often uneducated community members. However, this is an important interface between not simply the particulars of state law and custom, but the very purposes of social ordering and the means by which it is undertaken. Holly Porter has observed and described the priority given to the maintenance of customarily appropriate social relations, over and above any conception of justice by legal process, by contemporary Acholis. ${ }^{24}$ Social harmony, as observed by Porter, is not inimical to ideas of justice, as retribution and/or reparations often figure. However, the needs of kinship groups to maintain or achieve harmonious relations seem to be the ultimate goal of interventions after wrongdoing. Individual redress or avengement or the punishment of an individual tend to be side issues in a context where concepts of 'victim' and 'perpetrator' are attached to kinship groups rather than to individuals. Within clans and families, normative justice can be a minor concern relative to maintenance of appropriate relations.

The data discussed here seems to confirm this. Multiple responses referred to the necessity of parties reaching agreement or compromise in achieving a successful resolution. Especially in the case of intra-family or intra-clan disputes, the issue was often not about who was in the right as much as what both parties could accept and agree to. As a respondent who was both a Parish Chairman and a clan elder told us, "[t]he case is between relatives and so the [Parish] court told them that they should come to an understanding between themselves, and that if a ruling has to be made then this will spoil their relationship". 25

Bringing two parties together in agreement may be a long process, but custom allows for patience and perseverance in such matters, even if today this may take the form of disputes being played out in a variety of different forums, as seen in the following case between a man and his brother's widow: ${ }^{26}$

The dispute was resolved, though the mediation went through many steps. The first step was through the family members, but it failed, hence it was forwarded to the rwot kweri, but he also failed. ${ }^{27}$ The third mediation

\footnotetext{
24 H. E. Porter, After Rape: Justice and Social Harmony in Northern Uganda (PhD Thesis, London School of Economics and Political Science, London, 2013); Porter, supra note 18.

25 LCII Chairman and clan elder, Odek, Gulu, August 2012.

26 In this and all the following quotes, names of parties have been changed.

27 A rwot kweri (pl. rwodi kweri) is a 'chief of the hoe' elected by a community in a subdivision of a village to administer and oversee land organisation and collective farming. They are elected on the basis of their local land knowledge and community trust for an
} 
was done by the LCII court, but it also failed then later it was forwarded to the sub-county court, though it as well failed. Lastly, Mrs Akello forwarded the case to the high court and from there, the ruling was that since Mrs Akello was married into the family and because of the children, then she has the right to use the land. Hence she retained the land ownership. Currently, Mr Ocen doesn't disturb Mrs Akello because after the court ruling, they had a family meeting to advise Mr Ocen accordingly and traditionally. Mr Ocen has become the caretaker of Mrs Akello and her children, thus there isn't any further dispute. ${ }^{28}$

Clearly taking a case like this through multiple forums has a cost, and is often dismissed as 'forum-shopping', indulged in by land grabbers, the opportunity for which is seen as a failing of current dispute resolution systems. ${ }^{29}$ Perhaps it is, but the above description obliquely iterates a further factor favouring, given the context, a system of community involvement, consensus around compromise, and a goal of social harmony. This is that in practice, there are extremely rarely means for courts to enforce their decisions. In the above example, until Mr Ocen acknowledged that he was in the wrong, none of the bodies that had found against him were in a position to oblige him to return the land to his brother's widow, Mrs Akello, including the magistrate's court. In the end this was achieved not by the court, nor any part of the justice, law and order sector, but by a family meeting, presumably strengthened since its first attempt at mediation through corroboration by all the subsequently involved bodies.

Due to the lack of enforcement resources, actual outcomes of formal processes tend to reflect the power, physical, political or economic, of the parties. Where a court ruling is rejected by the losing party and needs to be physically enforced, this requires mobilisation of court brokers and/or the police, usually only options for the rich. It is hence very common for land dispute cases 'resolved' by formal courts to persist. However, as the problem of corruption in the courts is endemic, this may not reflect injustice. In the following example, there is no information as to who has the stronger moral and customary claim to the land. It is implied, however that Mrs Ajok is only able to pursue and probably win the case due to her access to money through her expatriate children:

indefinite period and are usually one of the first lines of mediation in local land disputes. See Porter, supra note 24, pp. 113-115; Hopwood and Atkinson, supra note 5, p. 27.

29 C. Burke and E.O. Egaru, Identification of Good Practices in Land Conflict Resolution in Acholi (United Nations Peacebuilding Programme, Kampala, 2011) p. 9. 
The dispute has not yet ended because Mrs Ajok has forwarded the case to the magistrates court. Olanya Dennis and five other households are still living and using the land. Initially, Mrs Ajok had Olanya Dennis arrested, but the family members came together with the other five households and made the police release him, and on return they vowed to continue living there and using the land. Currently, Olanya Dennis and the other five households are still living on and farming the land, and they say Ajok will never make them to become her slaves even though she believes in the power of the wealth of her children who are based in the United Kingdom. ${ }^{30}$

Not only are security systems inadequate to enforce court decisions, they are unable to enforce compliance with procedure, or even to protect adjudicators, as in this example:

When Mrs Legum forwarded the case to the LCII [Parish] court, Mr Kilama never turned up, but he sent information to the LCII [Parish Chairman] that if he doesn't want to be killed, he shouldn't go to the land to mediate, thus he never went because of fear. Later, because the LCII didn't mediate the dispute, Mrs Legum decided to forward the case to the sub-county, though it was not tried since Kilama again failed to attend. His deliberate failures to attend and the threats he makes show clearly that the land doesn't belong to him, but to Mrs Legum. Currently the case has been forwarded to the office of the RDC though it hasn't yet been dealt with, since the RDC has been transferred to another district. ${ }^{31}$ Mrs Legum is now frustrated and Kilama is continuing to use the land as his and there isn't any authority to help her. ${ }^{32}$

The reluctance on occasion of elders and lower courts to make judgements, combined with the fear of corruption in both government and customary bodies, were among the reasons given by some respondents to advocate for civil society involvement. ${ }^{33}$ One respondent stated that "land wrangles should be

\footnotetext{
$30 \quad$ LCII Councillor, Bungatira, Gulu, February 2014.

31 'RDC' refers to the Resident District Commissioner - a Presidential appointee with responsibility for security in a district.

$3^{2}$ LCII Councillor, Awach, Gulu, September 2012.

33 See Peace, Recovery and Development Plan 2, <www.prdp.org.ug/>, visited on 9June 2015. Under one strategic objective $\left(\mathrm{SO}_{4}\right)$ of the second phase of the second Peace, Recovery and Development Plan (PRDP II) for Uganda's conflict-affected northern and eastern
} 
handled by independent bodies like non-governmental organizations (NGOs) because the rich people are always winning cases because of the prevailing corruption in Uganda. In some places, elders from the office of the chief are using their power to take land from people and then rent it out". ${ }^{34}$ While a number of respondents argued that NGOs should become actively involved in dispute resolution, there seem to have been few instances where this has taken place, and in the one instance where NGO involvement was described in some detail, the outcome was unsatisfactory, not least due to a disturbing suggestion that the NGO adopted a partisan and even juridical role:

The case was not settled since Mrs Lakica rejected the mediation by the LCII and the rwot kweri by refusing to sign the acceptance letter, though her children signed. However, Mrs Lakica forwarded the case to Norwegian Refugee Council and their mediation and ruling favoured Mrs Lakica. This raised the anger of the community about the negative ruling against Ogen. After that, Ogen filed the case in the high court, but it has not yet been ruled ... Though the Norwegian Refugee Council ruled against Ogen, the community made it a point that neither party should use the land, nor anyone else from the community, as they wait for the ruling from the high court. ${ }^{35}$

Other respondents saw the appropriate role of civil society as boosting the skills, confidence and legitimacy of community dispute resolution actors. As one respondent recommended:

My advice is that if at all there is any NGO that can provide civic education to the mediators from within the local communities, so that they have respect, then this would reduce the level of land disputes, which can even lead to killings. Secondly, the courts should be prohibited because it is these very courts that do not rule appropriately due to bribery, making poor people lose their land. ${ }^{36}$

It is impossible to define what constitutes an acceptable level of disputes, though it is unreasonable to expect that there will be none at all. These respondents, in

districts, Alternative Dispute Resolution, 'ADR', is now a key element for donors' access to justice programmes. It involves trainings and manuals. 
the front line of serious dispute resolution, did not complain of being overwhelmed by numbers of disputes, but rather of the difficulties inherent: lack of means of enforcing rulings, lack of confidence that they were doing the right thing and personal and community risks. For example, 26 per cent of disputes where one or both parties were women involved violence, while 13 disputes (six per cent) involved a total of 21 killings. These figures are comparable to levels of violence and murder in all reported disputes. While disturbing, even these figures need to be considered in relation to high levels of violence and murder in contemporary Ugandan society.

The above findings are of a pattern of dispute resolution through mediation seeking compromise in pursuit of social harmony; lower level state actors actually function as embedded community actors, while higher levels of the justice, law and order sector sometimes play a role, but rarely a decisive one. Though these findings are not specific to women as principle parties to land disputes, they are highly relevant to issues of women's land security. The following sections relate more specifically to what is contested by women, and how custom is responding to current issues.

\subsection{Cognate Land Claims}

An Acholi woman marries into a different clan, and on completion of the marriage rituals and payments of bride price, she acquires a status within her husband's clan, with associated claims to land access. Bride price is seen as a resource for the recipient family to in turn fund the marriages of their sons, and in particular the brothers of the bride; thus the wealth circulates throughout the region, cementing alliances between different clans. If her husband dies, traditionally a widow will be 'inherited' by one of her brothers-in-law in a levirate marriage. Should a marriage break down, both families will seek to reconcile them together, but if it is concluded that the husband's behaviour is intolerable, the wife will return to her birth clan and, depending on the circumstances, the bride price may become repayable. ${ }^{37}$

These practices have changed in a number of ways, to an extent resulting from the extreme poverty and the social disruption caused by displacement over the period since 1995 (and perhaps earlier, as the Acholi lost their cattle, which represented most of their disposable wealth, in the late 1980s), but also by changing demographics and AIDs. Displacement affected clan cohesion, and responsibility for raising money for the bride price has latterly fallen to 
immediate families rather than being spread more broadly. ${ }^{38}$ In the ID P camps, families had few if any resources in a context where they were dependent on food aid supplemented by what little they could grow on rented land around the camps. Any surpluses tended to get spent on health care or school costs in well-functioning families, or on alcohol in very many others. Child-headed households, where both parents had died through the war or from road accidents or AIDS or other diseases, and where the extended family was unable or unwilling to provide for their orphans became common.

As they grew up, young people, whether orphaned or not but almost all without resources, sought partners. Fathers and brothers of girls took a range of attitudes to their 'husbands', some foregoing any great expectation of bride price, others recognising that the full amount could not be paid quickly, but maintaining pressure for gradual instalments. Rather than reducing the amounts involved, poverty seems to have inflated the expectations of brides' families.

Whether or not the men and their families are being pressured for bride price, its non- or partial payment results in couples being in a state of marital limbo. ${ }^{39}$ These and other factors have resulted in massive levels of marital instability, leading to very many young women caring for children alone, or living with men who are not the fathers of their children. In the context of customary land claims, this has created much confusion. While separation and divorce were not unknown, they seem to have been quite rare in pre-displacement Acholi, approached on a case-by-case basis by the clans involved. Today they are extremely common.

The traditional option for rural women who separate from their husbands is to return to their paternal clan, but their land access there is frequently challenged. One sub-county court member told us, "the major cause of land disputes are girls who marry, but then go back to their paternal homes with children, and later the children begin claiming land ownership". 40

Traditionally, besides bride price for the woman, the husband's clan would also have made various payments $(l u k)$ for children born of the union. ${ }^{41}$ Where

38 Girling, supra note 6, p. 39 reports the clan of the husband's mother frequently contributing to bride price, although primary responsibility lay with the clan of the husband's father.

39 Even where bride price has been paid, few couples take the further step of registering their marriage. As a result most land, property and inheritance law relating to wives and widows does not apply to the overwhelming majority of women. LCIII Court Committee member, Labongo, Kitgum, August 2012.

41 Porter, supra note 24, pp. 191-194. 
luk has been paid, in the event of separation children would stay with the mother until the age of seven; thereafter they would return to the father as members of his clan, with attendant inheritance and land rights. Where, as is now often the case, luk has not been paid, or where the father's family lack the will or resources to care for the children, problems occur. While there seems to be a general tendency to accept divorced women back into their paternal homes, how strong their land claims are, and the status of their children (in particular, whether they have claims to inherit), are widely contested by male family members, and this seems to represent an area where custom is evolving, with elders and communities tending to support such women's claims, and sometimes, their children's. Girling and Finnström noted that strong ties between children and their mother's clan and particularly her brother's clan increased chances of acceptance back into maternal homes. It seems that the maternal clan is still seen as a refuge for individuals of both sexes, and sometimes as a source of inheritable land, as in the instance below. ${ }^{42}$

This land was given by a mother called Helen to her daughter Barbara in 1971. In 2011 Ogen [Barbara's nephew] started claiming that the land belonged to him, so he decided to chase Barbara away, saying that a woman has no rights to own land. After the case was settled [in favour of Barbara], Ogen rejected the decision, yet all the community members were supporting Barbara. ${ }^{43}$

Where a woman never married, her claims to her father's clan land seem strong, if still contested on occasion: "It was clearly stated by the clan elders that the land belongs to Susan because it was given to her by her brother, so how can [her nephew] Okema claim the land from his aunt who was not married in another clan?"44

\subsection{Marital Land Claims}

Attempts by their in-laws to evict widows from the land they occupied with their late husbands is a common phenomenon. About 30 per cent of the reported disputes involving a female party involve a brother-in-law or other male relative seeking to evict a widow from her land.

42 Girling, supra note 6, pp. 39-40; S. Finnström, Living with Bad Surroundings: War, History and Everyday Moments in Northern Uganda, (Duke University Press, Durham, North Carolina, 2008) p. 34.

43 LCII Chairman, Pajule, Pader, August 2012.

44 LCIII Chairman, Lataya, Pader, August 2012. 
Traditionally a widow was inherited as a wife by one of her brothers-inlaw, and it seems that this sometimes still happens, although much more rarely following the AIDS pandemic. Any children of the union are part of the husband's clan and the responsibility of their paternal uncles. If still children, they remain under the care of their mother who holds their share of land in trust for them. If adults, they become protectors of their mother if widow inheritance does not take place.

In almost all of the resolved disputes involving widows, their claims were successful. Where such disputes remained unresolved, it was usually because the male challenger refused to accept the ruling of whatever process had transpired; usually these hard-to-resolve cases are presented as more or less overt instances of culpable land grabbing. However in many cases the losing party would seem to eventually accept the outcome of mediation and family harmony is restored.

Why this pattern of male family heads seeking to evict women, whether born or married into the clan, is so common probably varies with different land management models and pressures. In some instances where land is commoditised, it may be a case of opportunistic greed. In other cases population pressures may be the issue. Whether control of clan land is exercised by clan leaders or by family heads seems to vary significantly across Acholi. Where parcels of land are specific to families and in short supply, problems arise. In such cases, allotting land for all entitled family members falls to the family head, even if the land is ultimately under the control of the clan. Where there is an actual or feared future land shortage for that family, the head will attempt to diminish the number of claimants, favouring male clan members with the most overt traditional claims. Clan elders on the other hand are, it would seem, more concerned with the interests and obligations of the clan as a whole to its individual members. Thus women are able to retain their land access when this is threatened by heads of families, by appealing to the clan elders. This would seem to be supported by consideration of LCMMT data from across Acholi. Where land was reported to be under the control of the whole clan, intra-clan disputes seemed to be much less likely to occur. ${ }^{45}$

\subsection{Women, Guests and the Informal Land Market}

While the above findings suggest that women are successfully establishing their claims to both patrilineal and marital clan land, many others of both genders are being forced off land, or are increasingly vulnerable, through weaker associations with the dominant clans. These 'guests' are people who 
have been given land by members of the dominant clan or who have inherited such gifted land. Land is traditionally given to friends, and relations by marriage, without the terms being spelled out, let alone documented. Historically and traditionally, the typical terms would be that: 1) guests are there at the discretion of the gifting clan, and that the gifting clan may reclaim the plot, given cause; 2) the size of the plot of land in question is fixed and cannot be expanded without the permission of the gifting clan; 3) the plot can be passed on to the guest's heirs and that the gift is potentially indefinite; and 4) remaining on the land is conditional on the guests being good neighbours and adopting clan mores.

However, as such terms are not written, they are open to widely differing interpretations. Over the course of a couple of generations, guests who were liked may be admitted into the host clan. In the past, if they were told to vacate the land for whatever reason, guests would usually have had other options returning to their clan of origin or seeking out another in-law clan. Today land pressures mean that this is likely to be much more difficult - many clans will be resistant to new inward migration rather than welcoming.

All of the above needs to be understood in terms of negotiability. Guests do not have rights to land in the Western sense (it is arguable that no one does), though they have claims through having developed land or through having buried their forebears there. In practice, guests may be central to a clan community. It is often generally forgotten who is and who is not a guest, and there are instances of elderly land grabbers inventing false genealogies to claim that certain clan members are in fact guests. On the other hand, problems with guests often arise through them selling, or trying to sell, land. Guests may be more prone to trying to sell land because they have less attachment to it, but perhaps also because they feel less secure and are trying to monetise their principal asset before it is taken from them.

Gifting of land can be seen as the precursor of the informal land market as it has emerged. While small parcels of land have been traded and formally tenured in the main towns, Gulu and Kitgum, for nearly a century, in rural areas the norm was for communities to gift land not only to guests, but also to churches, hospitals, schools, health centres, local government and other institutions for community benefit. However, the terms of such gifts tend to be as unspecific and undocumented as those to individuals. Acholi are widely familiar with a certain notion of land as a marketable asset due to the almost universal practice of renting small plots for farming in the vicinity of IDP camps, to supplement inadequate food rations. While this has introduced the notion of renting and of the 'paying guest' it has still left the notion of a permanent sale obscure to many. Where the relationship to land is ontological, as described by 
Okoth-Ogendo, permanent alienation may be hard to conceptualise. ${ }^{46}$ It is extremely common for land sales - and of land gifts to institutions that the latter assumed were permanent - to end in dispute, sometimes with the original vendors or gifters, often with their heirs.

The most obvious problem with trading clan land is that the negotiability of rights or claims to the land means that it is often extremely difficult to say who all the 'owners' are. In more traditional villages, an individual or family does not have permanent control over a specific parcel of land or a given amount of farmland (although might make a permanent claim to a small homestead). On the basis of this, it is often argued that clan land is inalienable and that the informal market in customary land is inherently immoral and/or illegal. As Chimhowu and Woodhouse explain, even where customary land is recognised in law, in the absence of formal registration of land there perhaps cannot be a legal customary land market. ${ }^{47}$ This is not, however, an argument for formalising or titling customary land, as the hazards of the land market, formal or informal, for very poor people in places where there are neither jobs or safety nets, are massive. In such a market, distress sales are likely to predominate leading to landlessness and extreme poverty. ${ }^{48}$

One of the arguments made in favour of informal land markets is their potential to offset women's disadvantages under customary tenure - if they are deprived of land access by patriarchal and discriminatory customary authorities, they can gain land access by renting or buying. ${ }^{49}$ While few women are able to afford to buy land - even where this can be made to work - very many Acholi women (and some men) rent plots to farm on, often as a supplement to day labouring or petty business. In this context, the market in rented land is an essential element of survival for many. Buying and selling is a different matter. Land transactions frequently don't work, perhaps because the concept of fixed

46 H.W.O. Okoth-Ogendo, 'Legislative approaches to customary tenure and tenure reform in East Africa', in C. Toulmin and J. Quan (eds.), Evolving Land Rights, Policy and Tenure in Africa (Department for International Development, International Institute for Environment and Development, University of Greenwich National Resources Institute, London, 2000) pp. 123-34.

47 See A. Chimhowu and P. Woodhouse, 'Customary vs. Private Property Rights? Dynamics and Trajectories of Vernacular Land Markets in Sub-Saharan Africa', 6:3 Journal of Agrarian Change (2006) pp. 346-371 for a comprehensive account of this debate.

48 Ibid., p. 347.

49 S.O. Okuro, 'Struggling with In-Laws and Corruption in Kombewa Division, Kenya: The Impact of HIV/AIDS on Widows' and Orphans' Land Rights', in B. Englert and E. Daly (eds.) Women's Land Rights and Privatization in Eastern Africa (Fountain Publishers, Kampala, 2008) pp. 132-135. 
plots of land functioning as commodities, and in which a sale is a final event, doesn't resonate with most people. Sellers often seem to assume it is a temporary deal - something like a short lease - and that they have the power to change the terms or revoke the sale at any time should they choose, as in this case:

The fact is that Okello bought land from Pauline's late husband in 1994, and recently Okello wanted to sell part of the land; but Pauline was of the view of stopping Okello so as to gain much more from the land by selling it to another person. Pauline's argument was that Okello bought the land cheaply from her late husband, yet the land is big, so her reasoning was that Okello should not sell the whole land because part of the land still belongs to her. Later, when Okello produced the sale agreement which contained the sketch map of the land, it was clearly resolved that the land belongs to Okello because she had also signed the sale agreement..$^{50}$

As things currently stand, whether a land transaction is conclusive or not, and what has been sold, is a matter of (contemporary) custom; whether or not local authorities have an interest in maintaining a 'fair' market, or the ability to influence it if they do, is a very local matter.

\section{4}

\section{Conclusions}

Overall these findings suggest that land dispute resolution actors are providing a substantial degree of land access security to rural Acholis, including women. It would be wrong to idealise them, however, because by their own account, there are many cases where parish-level leaders are unable to protect vulnerable people, and even themselves, from elite and/or moneyed land grabbers, as well as, sometimes, from aggrieved parties. Others, including women, are unfairly denied access to land, but are constrained in a host of ways from pursuing a complaint even at the most local level. There are 'guests' who have been evicted, or whose security on land they have occupied for generations is threatened, due to the nature of custom as it is currently understood and applied.

State actors in the shape of Village and Parish Councils play a central role in customary land administration. However the role played by the state qua state is seemingly very small: Village and Parish Councils are playing community and customary roles that have little to do with their formal functions. Perhaps 
this is a position they adopt to gain community approval, but it is more probable that this is the de facto role allocated to them by a state with little interest in intervening, beyond protecting its own security interests, at a local level.

The 'law' that local council uphold is that of custom; their methods are mediation rather than adjudication; their goal is social harmony rather than justice; and their enforcement resources are social pressure and community action rather than the police or higher courts. The justice, law and order sector is not completely absent, but in very few of the 202 reported cases here examined did it have a conclusive role in dispute resolution: sub-county and magistrates courts are periodically involved, but rarely decisively, often referring issues back to community leaders on the basis that they lack the information to make an informed judgement, at other times making rulings that they are unable to enforce. Ben Jones has argued that state services in relation to land, including the police and the higher courts, are of marginal functionality and relevance in rural Uganda. ${ }^{51}$ LCM MT findings likewise suggest that the kinds of intra-family or intra-clan disputes that women find themselves party to do not attract much state attention.

Almost all of the instances noted in the findings above give a picture of customary land principles and dispute resolution methods as negotiable, and undertaken in the cause of something that might be termed social harmony, rather than justice as a legal process. This challenges those understandings of customary 'law' and 'land rights' that have been in currency since the start of the colonial era, namely that these are directly comparable to Western law and Western rights and hence can be codified and incorporated into the formal justice system. ${ }^{52}$ These findings suggest that customary dispute resolution systems work on the basis of loose principles and overlapping claims that cannot be translated into 'law' and 'rights', at least not without dispossessing large numbers of people of their land access.

Land law reform might potentially improve land access security for some by influencing custom to give greater normative weight to the claims of women, but there are other, probably more effective, means by which this might be undertaken. Law reform carries many risks, including that of shrinking or

\footnotetext{
51 Jones, supra note 23, p. 164.

$5^{2}$ Not that codification was attempted in the case of Acholi (see supra note 16). Throughout Uganda and much of the British Empire, bifurcated legal systems - 'formal' and 'customary' - were adopted by colonial governments ostensibly as culturally responsive solutions, especially in situations of indirect rule. In practice, 'customary law' absolved the ruling power of a great deal of administrative complication and expense, which may also explain why it has persisted in much of post-colonial Africa.
} 
undermining the space in which customary land management now operates. This is dangerous as the formal state is not at this time able to fill any such space created. Perhaps the most practical intervention to strengthen land security for women is by responding to the local leaders who provided the information for this study, who often asked for help, which in the spirit of customary practice might take the form of dialogue on how to address new challenges.

This study identifies a situation in which customary communal land processes in Acholi are providing a degree of security for women within the customary system, with claims based on heredity seemingly having evolved as stronger, in the eyes of communities, than in the past. There is no obvious means suggested in these findings whereby the state, as it is now or in the foreseeable future, could offer greater or even equivalent protection, whether through law reform, formal titling or otherwise. 